\title{
IMPAK PENUBUHAN IMBAK CANYON CONSERVATION AREA (ICCA) KE ATAS KOMUNITI SETEMPAT: KAJIAN KES DI KAMPUNG IMBAK, TONGOD, SABAH, MALAYSIA
}

\author{
THE IMPACT OF IMBAK CANYON CONSERVATION AREA (ICCA) ON LOCAL \\ COMMUNITY: A CASE STUDY OF IMBAK VILLAGE, TONGOD, SABAH, MALAYSIA.
}

\author{
Andreas Pingking \& Rosazman Hussin (PhD) \\ Borneo Institute for Indigenous Studies (BorIIS), \\ Universiti Malaysia Sabah \\ reasand94@gmail.com; azzs@ums.edu.my
}

\begin{abstract}
Community involvement in a conservation area has become a critical issue especially in the context of a nature conservation area. The success of the development in the conservation area is essential to involve local community participation either in the process of decision-making or the local community is gains advantages benefits brought about by the conservation area. This is because the establishment of the Imbak Canyon Conservation Area (ICCA) has a positive and negative impact on the local community. The local community of Imbak village has been stayed in nearby areas for a long time ago. The Sabah State government, however, gazette Imbak Canyon as a Class 1 (Protection) Forest Reserve in 2009. Thus, there are some challenges faced by the local community to sustain their daily livelihoods practices and activities of which were based on forest resources used before the ICCA was established. This study applied a qualitative approach. An in-depth interview of the data collection method was used; six informants comprising the village chief of Imbak, residents of Kampung Imbak, and three other villagers are working for staff at the Imbak Canyon Conservation Area were interviewed. The research findings show that there is also a positive impact attained by the local community as a result of their involvement in ecotourism activities such as become as homestay providers in the ICCA. Therefore, the results of this study will hopefully provide some grounded data for the stakeholder to consider the policy of so-called the communitybased conservation approach in the ICCA.
\end{abstract}

Keywords: Imbak Canyon Conservation Area (ICCA), Community Participation, Environmental Conservation, Biodiversity, Imbak Canyon

\begin{abstract}
ABSTRAK
Penglibatan masyarakat dalam kawasan perlindungan merupakan isu kritikal terutama dalam konteks kawasan pemuliharaan alam semulajadi. Kejayaan pembangunan di kawasan perlindungan dan pemuliharaan alam semulajadi adalah sangat penting terutamanya untuk melibatkan penyertaan masyarakat setempat dalam proses membuat keputusan atau komuniti setempat mendapat keuntungan daripada kawasan perlindungan atau pemuliharaan alam semulajadi tersebut. Ini kerana penubuhan Imbak Canyon Conservation Area (ICCA) memberi kesan positif dan negatif kepada masyarakat setempat. Masyarakat setempat di kampung Imbak
\end{abstract}


telah lama tinggal berhampiran di kawasan ICCA sejak dulu lagi. Bagaimanapun, pihak kerajaan Negeri Sabah telah mewartakan Kawasan Imbak Canyon sebagai Hutan Simpan Kelas 1 (Perlindungan) pada tahun 2009. Oleh itu, terdapat beberapa cabaran yang dihadapi oleh masyarakat setempat demi meneruskan amalan dan aktiviti penghidupan harian mereka selama ini yang berasaskan sumber hutan sebelum ICCA ditubuhkan. Kajian ini menggunakan pendekatan kualitatif. Kaedah temu bual mendalam adalah kaedah pengumpulan data yang digunakan; enam orang informan yang terdiri daripada ketua kampung Imbak, penduduk Kampung Imbak dan tiga orang penduduk kampung yang bekerja sebagai kakitangan di kawasan Pemuliharaan Imbak Canyon telah ditemu bual. Dapatan kajian menunjukkan bahawa terdapat kesan positif penubuhan ICCA ke atas ahli komuniti setempat sebagai hasil daripada penglibatan mereka dalam aktiviti ekopelancongan seperti menjadi penyedia inap desa di ICCA. Oleh itu, hasil kajian ini diharapkan dapat memberikan sumber data lapangan kepada pihak berkepentingan untuk mempertimbangkan kebijakan pembangunan alam semulajadi yang disebut sebagai pendekatan pemuliharaan berasaskan komuniti di ICCA.

Kata kunci: Kawasan Konservasi Imbak Kanyon (ICCA), Penyertaan Komuniti, Pemuliharaan Alam Sekitar, Kepelbagaian Biologi, Imbak Canyon

\section{Pengenalan}

Penubuhan kawasan perlindungan alam semulajdi pertama di dunia, Yellowstone, USA, pada tahun 1872, adalah tindak balas dari tamadun barat terhadap kemusnahan biodiversiti yang tidak terkawal dan tiadanya perkhidmatan ekosistem (Lane 2001, Pretty dan Smith 2004, Chape et al. 2008). Sejak itu, bilangan kawasan perlindungan di seluruh dunia telah meningkat dengan pesat. Pendekatan berasaskan komuniti untuk pemuliharaan alam semulajadi telah menjadi agenda utama kebanyakan negara sebagai reaksi kepada kegagalan pemuliharaan alam semulajadi seperti hutan dan lautan melalui pendekatan konvensional dengan berlaku kepupusan dan pencemaran hutan dan lautan atas nama pembangunan ekonomi. Dunia pada masa sekarang mula sedar bahawa faktor-faktor sosial dan ekonomi semakin dilihat sebagai kunci kepada kejayaan pemuliharaan dan perlindungan alam sekitar (Ghimire \& Pimbert 1997). Penekanan penglibatan masyarakat dalam usaha pemuliharaan alam sekitar atau alam semulajadi adalah didorong oleh slogan bahawa jika pemuliharaan alam semulajadi dan pembangunan dapat dicapai secara serentak, kepentingan kedua-duanya iaitu pengekalan alam semulajadi dan faedah ekonomi dapat dicapai secara seimbang. Oleh itu, naratif konvensional bahawa konsep atau pendekatan 'pemuliharaan secara benteng atau kubu' dalam memelihara alam semulajadi semakin kurang relevan dan kurang sesuai apabila sebahagian besar idea dan pendekatan pemeliharaan alam semulajdi ini telah berubah kepada naratif "pemeliharaan alam semulajadi berasaskan komuniti dan pembangunan lestari” (Murphree 2002: 2).

Sehubungan dengan itu, pemuliharaan alam semulajadi berasaskan komuniti (Community-based Conservation - CBC) adalah berdasarkan kepada idea bahawa jika pemuliharaan dan pembangunan dapat dicapai secara seimbang, kepentingan kedua-duanya iaitu kelestarian alam semulajadi dan kesejahteraan hidup manusia boleh dicapai (Berkes 2004). Kepentingan menggabungkan pendekatan yang lebih partisipatif dalam proses membuat keputusan tentang mengekalkan protected area dan memupuk pelaksanaan strategi pemuliharaan berasaskan komuniti telah banyak dijelaskan dalam kajian lepas (Brown 2003, Grainger 2003, Pretty dan Smith 2004, Anthony 2007, Reed 2008). Aswani dan Weiant (2004) menegaskan bahawa, apabila masyarakat tempatan dipinggirkan daripada terlibat secara langsung atau tidak langsung dalam pengurusan kawasan perlindungan alam semulajadi seperti hutan dan keperluan kehidupan harian mereka diabaikan maka usaha pihak berkuasa untuk 
melindungi kawasan tersebut menjadi sangat sukar terutama dalam usaha melaksanakan dasar pengguatkuasaan di kawasan pemuliharaan. Namun demikian, ramai pengkaji masih tidak jelas sejauhmana penglibatan ahli komuniti tempatan dalam proses membuat keputusan berkaitan pemeliharaan kawasan perlidungan alam semulajadi menyumbang kepada peningkatan kepatuhan ahli masyarakat setempat terhadap dasar perlindungan di kawasan alam semulajadi tersebut (Wilshusen et al 2002, Mascia 2003, Pretty dan Smith 2003, Aswani dan Weiant 2004, Hayes 2006, Ban et al. 2008).

Penubuhan 'protected area' seperti Imbak Canyon Conservation Area (ICCA) di negeri Sabah merupakan satu usaha bersama Yayasan Sabah dan juga Petronas. Dalam konteks lain penubuhan kawasan perlindungan alam semulajadi ini biasanya dikaitkan dengan pembangunan mempunyai kesan positif dan juga negatif kepada ahli komuniti setempat. Selain itu, isu berkaitan kawasan perlindungan alam semulajadi sering menjadi isu panas kerana penubuhannya boleh mendatangkan kesan negatif kepada kehidupan harian ahli komuniti setempat. Justeru, pada masa kini, bagi mengimbangi keperluan pemuliharaan alam semulajadi dan kebajikan hidup ahli komuniti setempat, kawasan ICCA telah dibuka sebagai kawasan ekopelancongan. Melalui pendekatan ini pihak berkuasa berharap boleh memberi faedah kepada penduduk setempat mendapat faedah ekonomi dan pekerjaan melalui ekopelancongan (Scheyveness, 1999; Ross \& Wall, 1999; Weaver, 2001). Pemuliharaan kawasan alam semulajadi melalui ekopelancongan boleh memberi banyak kesan positif kepada komuniti setempat. Justeru, tahap penglibatan ahli komuniti yang aktif dalam ekopelancongan boleh menyumbang kefahaman mereka terhadap usaha pemuliharan alam semulajadi kerana keduaduanya iaitu aktiviti ekopelancongan dan alam semulajadi adalah saling memerlukan antara satu sama lain. Hasilnya berlakunya pemerkasaan komuniti dalam program ekopelancongan dan pemuliharaan kawasan alam semulajadi tersebut (Pretty, 1995; Scheyvenes, 2002). Persoalannya, sejauhmanakah penubuhan ICCA di Sabah ini memberi kesan positif dan negatif ke atas penghidupan harian ahli komuniti yang tinggal berhampiran di kawasan ICCA ini iaitu di kampung Imbak, Apakah cabaran yang mereka hadapi untuk terlibat dengan lebih aktif demi memperkasakan penglibatan mereka dalam aktiviti ekopelancongan dan pemuliharaan alam semulajadi di kawasan ICCA ini.

\section{Pendekatan Konservarsi Berasaskan Komuniti (Community-Based Conservation Approach-CBCA)}

Pendekatan konservasi berasaskan komuniti (CBC) dirancang dengan pandangan bahawa komuniti setempat memainkan peranan yang penting untuk menentukan keberhasilan usaha konservasi. CBCA diharapkan dapat memberikan manfaat bagi masyarakat setempat yang akan mendukung usaha melestarikan kawasan hutan serta membantu meningkatkan ekonomi. Selain itu konservasi berasaskan komuniti ini telah mendapat perhatian lebih daripada pihak berkeentingan dalam beberapa tahun kebelakangan ini sebagai alat yang berpotensi untuk meningkatkan penglibatan masyarakat dalam inisiatif pemuliharaan. Secara umumnya CBCA didefinisikan sebagai perlindungan sumber daya alam atau biodiversiti untuk dan dengan Bersama masyarakat setempat. Di mana makna konsep utamanya adalah kewujudan bersama manusia dan alam semula jadi (Western \& Wright's, 1994). Ruiz-Mallen et al. (2015) berpendapat bahawa CBCA dapat didekati dengan dua cara berdasarkan pengaturan perlembagaan yang mendasari program pemuliharaan alam semulajadi dan hasil yang diharapkan, yaitu (i) pemeliharaan berpusatkan orang (individu) dan (ii) pemuliharaan berasaskan masyarakat atau komuniti yang bergantung pada keberadaan masyarakat yang didedahkan waktu latihan pengurusan alam semulajadi (berdasarkan pengaturan biasa). 
Pendekatan pertama bertujuan untuk menerima objektif dan pembangunan pemuliharaan dengan menjalin perkongsian antara komuniti setempat dan organisasi luar (kerajaan, NGOs dan sektor swasta). Ini mencakup pemuliharaan formal yang bertujuan untuk memberi penghargaan kepada masyarakat atas kepedulian mereka dan memotivasi mereka untuk terlibat dalam industri pemuliharaan yang baru diperkenalkan kepada mereka. Contohnya pengelolaan bersama inisiatif pemuliharaan di kawasan lindungan, projek ekopelancongan dan cadangan berasaskan masyarakat (Armitage, 2009; Stronza \& Gordillo, 2008). Pendekatan kedua menekankan CBCA sebagai rangkaian pengurusan sumber daya alam semulajadi yang menyokong penghidupan biodiversiti dan melalui proses percubaan serta mungkin berlaku kesilapan sepanjang tempoh programa pemuliharaan dan adaptasi tersebut (Berkes, 2009). Sehubungan dengan penglibatan ahli komuniti dalam usaha pemuliharaan alam semulajadi perlu disokong oleh program ekonomi lain yang selari dengan usaha pemeliharaan boidiversiti dan memberi pendapatan kepada ahli komuniti setempat dan program tersebut adalah ekopelancongan.

\section{Tipologi Penglibatan Komuniti dalam Pembangunan oleh Pretty (1995)}

Seccara umumnya, Pretty (1995) telah membangunkan Tipologi Penglibatan Komuniti dalam pembangunan. Tipologi ini akhirnya telah diaplikasi oleh pengkaji ekopelancongan dan penglibatan komuniti dengan meluas (Hussin, 2008; Eshun, \& Tichaawa, 2020). Tahap penglibatan komuniti yang ada dalam tipologi penglibatan komuniti oleh Pretty telah menjadi kayu ukur bagi kajian ini untuk menentukan tahap manakah komuniti terlibat dalam konservasi. Kajian tentang penglibatan komuniti bermula daripada isu reaksi komuniti terhdap pembangunan pelancongan (Arnstein, 1969) hingga kepada tipologi penglibatan komuniti oleh Pretty (1995) dan Tosun (1999). Dalam tipologi penglibatan komuniti ini bentuk dan tahap penyertaan komuniti dinilai dari tahap rendah (manupaltif) hingga ke tahap yang paling tinggi (penglibatan kendiri) dalam proses pembangunan. Pembangunan yang dikaitkan dengan penyertaan penduduk setempat dipengaruhi oleh dinamika antara hubungan kuasa dengan pengagihan kuasa membuat keputusan dalam peringkat tempatan atau lokal. Tambahan lagi, tipologi ini telah diaplikasikan dalam kajian ini untuk menilai bagaimana penglibatan bentuk dan tahap penglibatan komuniti mempengaruhi proses dan hasil pembangunan yang dirancang oleh pihak berkepentingan. Jadual 1, menunjukkan tujuh tahap penglibatan komuniti yang dibincangkan oleh Pretty (1995): 
Jadual 1: Tahap Penglibatan Komuniti dalam Pembangunan oleh Pretty (1995)

\begin{tabular}{|c|c|}
\hline $\begin{array}{l}\text { Bentuk dan tahap } \\
\text { penglibatan }\end{array}$ & Penerangan \\
\hline Penglibatan Manipulasi & $\begin{array}{l}\text { Penglibatan ahli komuniti bersifat lakonan. } \\
\text { Individu yang mewakili komuniti di meja rundingan tidak dipilih } \\
\text { secara rasmi dan tiada wakil penduduk terlibat yang biasanya } \\
\text { disuruh untuk mejayakan sesuatu projek. }\end{array}$ \\
\hline Penglibatan Pasif & $\begin{array}{l}\text { Penduduk yang terlibat biasanya disuruh untuk menjayakan sesuatu } \\
\text { projek. } \\
\text { Maklum balas atau respons penduduk tidak diambil kira oleh } \\
\text { pengarah projek kerana lebih menekan pendapatan ahli profesional. }\end{array}$ \\
\hline Penglibatan Konsultasi & $\begin{array}{l}>\text { Ahli komuniti terlibat dinasihatkan supaya terlibat sama dalam } \\
\text { projek. } \\
>\text { Agensi luar yang mengawal semua proses pembangunan. }\end{array}$ \\
\hline Penglibatan Insentif & $\begin{array}{l}\text { Ahli komuniti terlibat dalam menyumbangkan tenaga kerja untuk } \\
\text { mendapatkan faedah dalam bentuk nilai mata wang atau material } \\
\text { lain. }\end{array}$ \\
\hline Penglibatan Fungsi & $\begin{array}{l}\text { Ahli komuniti berfungsi dalam pembentukan sesuatu tindakan } \\
\text { secara kumpulan dengan agensi luar unutk mencapai objektif projek. } \\
\text { Tiada penglibatan dalam membuat keputusan kerana keputusan } \\
\text { projek telah ditentukan oleh agensi pembangunan luar. }\end{array}$ \\
\hline Penglibatan Interaktif & $\begin{array}{l}\text { Ahli komuniti terlibat dan kerjasama dengan agensi pembangunan. } \\
\text { Penglibatan dianggap sebagai untuk terlibat. } \\
\text { Penglibatan melalui proses pendidikan, mengukuhkan institusi } \\
\text { tempatan dan dapat mengawal sumber serta mencapai matlamat } \\
\text { projek. } \\
>\begin{array}{l}\text { Keputusan pembangunan pada peringkat tempatan dikuasai oleh } \\
\text { komuniti }\end{array}\end{array}$ \\
\hline Penglibatan kendiri & $\begin{array}{l}\text { Komuniti terlibat melalui inisiatif sendiri atau kendiri secara bebas. } \\
\text { Matlamat projek dicapai dengan jayanya. } \\
\text { Namun, penglibatan jenis ini memerlukan kerangka sokongan } \\
\text { daripada kerajaan dan badan bukan kerajaan (NGO). }\end{array}$ \\
\hline
\end{tabular}

Sumber: adaptasi daripada Mason, M. (2003: 119).

Sehubungan dengan itu, tipologi penglibatan komuniti dalam pembangunan oleh Pretty (1995) diaplikasikan dalam kajian ini bagi menilai tahap penglibatan komuniti di kampung Imbak dalam konservasi dan ekopelancongan yang telah dilaksanakan di kawasan ICCA. 


\section{Konsep Utama Kajian}

\section{Konservasi Melalui Ekopelancongan}

Konsep konservasi melalui ekopelancongan ini adalah bermaksud suatu bentuk pelancongan berasaskan sumber alam semula jadi yang berkesinambungan serta memberi tumpuan terutamanya pada pengalaman dan pembelajaran tentang alam semula jadi (bioddiversiti) dan dikendalikan secara beretika, berimpak rendah, tidak konsumtif, dan berorientasikan tempatan (kawalan, faedah dan skala). Ia biasanya berlaku di kawasan semula jadi dan harus menyumbang kepada pemeliharaan atau pemuliharaan kawasan tersebut (Fennel, 1999). Manakala Goodwin (1996) menyatakan bahawa ekopelancongan adalah pelancongan alam berimpak rendah yang menyumbang kepada pemeliharaan spesies dan habitat sama ada secara langsung melalui sumbangan untuk pemuliharaan dan secara tidak langsung dengan memberikan pendapatan kepada masyarakat tempatan yang cukup untuk orang tempatan hargai dan untuk melindungi kawasan warisan hidupan liar sebagai sumber pendapatan.

Selain itu, konservasi mempunyai maksud pemeliharaan, iaitu memelihara atau memulihara daya dukung, kualiti, fungsi dan keupayaan persekitaran secara seimbang (MIPL, 2010; Anugrah, 2008; Wahyudi dan DYP Sugiharto (ed), 2010). Tujuan konservasi adalah untuk mewujudkan pemeliharaan sumber alam semula jadi dan keseimbangan biologi ekosistem, sehingga dapat terus menyokong usaha untuk meningkatkan kesejahteraan dan kualiti hidup manusia. Disamping itu, konservasi juga memainkan peranan dalam usaha memelihara keupayaan dan penggunaan sumber alam semulajadi dan ekosistemnya secara harmoni dan seimbang. Hubungkait antara konservasi dan ekopelancongan ini adalah melalui peranan ahli komuniti melibatkan diri dalam usaha konservasi hutan dengan mengusahakan pelancongan (inap desa) yang menjadikan alam semula jadi sebagai daya tarikan (Hussin, 2008). Dengan itu, komuniti dapat sama-sama menjaga alam semula jadi seperti hutan dan hidupan liar samada terlibat secara langsung atau tidak langsung dengan konservasi yang dilaksanakan oleh pihak berkepentingan termasuk usaha mengurangkan kadar kemisikinan (Agyeman, Yeboah, \& Ashie, 2019).

\section{Konsep Penglibatan Komuniti}

Tosun memberi definisi konsep penglibatan komuniti sebagai "satu bentuk tindakan sukarela seseorang individu dalam mengambil peluang dan memikul tanggungjawab kemasyarakatan" (Tosun, 2000:614). Selain itu, penglibatan komuniti adalah satu proses di mana masyarakat berkerjasama sebagai penggerak pembangunan dan melibatkan diri dalam usaha pembangunan yang akhirnya akan memberi kesan terhadap keadaan dan taraf hidup mereka sendiri. Penglibatan komuniti juga memastikan bahawa keperluan dan inspirasi komuniti tersebut tidak diabaikan dan hasilnya ialah ahli komuniti itu akan mendapat didikan dan seterusnya diperkasakan (Tosun, 2000:615).

\section{Konsep Komuniti Setempat}

Konsep komuniti dalam bidang sains sosial sering digunakan secara longgar dan tidak tetap sehinggakan ia mendapat pelbagai definisi penggunaannya dalam sesuatu penyelidikan (Abdul Rahman, 2007:12-18). Namun menurut ahli sosiologi, komuniti merupakan satu unit organisasi sosial yang dalamnya terdapat manusia dengan kawasan dan unit kediamanya, melakukan pekerjaan untuk kehidupan, mengurus kehidupan keluarga dan anak-anak serta meneruskan 
sebahagian besar aktiviti kehidupan mereka. Sesetengah pengkaji menekankan tiga elemen penting yang mesti wujud bagi komuniti iaitu kawasan geografi atau lokaliti, interaksi sosial dan hubungan komuniti (Poplin, 1979: 8). Namun begitu, anggota-anggota masyarakat yang mendiami sesebuah kawasan yang sama tidak semestinya membentuk komuniti secara automatik sekiranya mereka tidak menjalin interaksi sesama mereka secara berterusan dan juga tanpa wujud rasa kekitaan terhadap jalinan hubungan sosial tersebut.

\section{Ulasan Kajian Lepas}

Satu kajian di Kenya berkaitan dengan pemeliharaan dan pemuliharaan hutan telah dijalankan pada tahun 2019 oleh Brian Rotich. Kawasan kajian beliau lebih tertumpu di kawasan Hutan Embobut, Cherangani di bahagian barat Kenya. Hutan tersebut merupakan satu sumber alam semula jadi dan ekosistem paling penting terutamanya kepada masyarakat pribumi di Cherangani/Sengwer. Hutan Embobut yang juga merupakan rizab hutan pribumi di Elgeyo Marakwet Country, Kenya dengan keluasan 21.933 Ha. Data dikumpulkan dengan menggunakan kaedah soal selidik, Focus Group Disccussion dan temubual mendalam serta analisis data menggunakan Microsoft Office Excel 2013. Sebanyak 42 orang responden yang tinggal di kawasan berhampiran dengan hutan tersebut. Dapatan kajian ini menunjukkan bahawa aktiviti ekonomi dalam masyarakat tersebut kadangkala berubah dari memburu dan mengumpul hasil hutan untuk ditanam dan majoriti responden $(35.7 \%)$ mengamalkan pertanian sementara (11.9\%) masih memburu dan mengumpul hasil hutan. Selain itu, 95.2\% responden mendapat manfaat daripada hutan dengan memperoleh banyak arang kayu hasil daripada hutan tersebut (71.4\%). Madu (26.2) dan ubat herba (21.4) adalah yang kedua dan ketiga paling banyak dituai daripada hutan Embobut.

Faedah dan produk lain yang diperolehi daripada hutan tersebut ialah tiang rumah, buahbuahan liar, sumber daging dan banyak lagi. Cabaran pemuliharaan di kawasan kajian termasuk pembasmian hutan secara haram, pembalakan haram, pembakaran arang, kebakaran hutan dan pencerobohan ke dalam hutan. Oleh itu, Pelaksanaan Hutan Cherangani Rancangan Pengurusan Strategik (2015-2040) perlu untuk menangani cabaran yang ada. Integrasi masyarakat pribumi ke dalam proses politik terutamanya dalam isu penggunaan tanah dan pengurusan hutan juga penting untuk memastikan kesejahteraan masa depan mereka pada masa yang sama mencapai matlamat pemuliharaan.

Selain itu, berdasarkan kajian Arthur Hoole (2008) tentang 'Program Pengurusan Sumber Berasaskan komuniti (CBNRM)' yang dijalankan di Namibia adalah satu langkah memberi pengetahuan mengenai pendidikan alam semulajadi kepada komuniti setempat. Kajian yang dilakukan oleh Arthur tersebut adalah bertujuan untuk mendapatkan tidak balas dan juga pandangan komuniti setempat terutamanya yang tanggal di kawasan Konservasi Ehi-rovipuka dan Taman Negara Etosha di utara Namibia. Tindak balas yang dimaksudkan ialah bagaimana pendapat komuniti sekiranya kawalan terhadap aktiviti berkaitan hutan lebih diperketatkan sehingga menghalang komuniti setempat melakukan aktiviti-aktiviti yang sudah lama mereka amalkan seperti memburu, memungut hasil hutan dan sebagainya. Namun, Program Pengurusan Sumber Berasaskan Komuniti tersebut dilihat dapat memberi manfaat kepada komuniti dan berjaya mewujudkan hubungan yang harmoni antara komuniti setempat, alam semula jadi dan pihak berkuasa. 
Manakala satu lagi kajian dilakukan berkaitan pengurusan sumber secara mapan di Ulu Kinabatangan oleh Normah Abdul Latif et al (2013) bertujuan untuk mengkaji pandangan tiga pihak berkepentingan utama (pihak kerajaan, sektor swasta dan komuniti setempat) berkaitan dengan isu-isu alam semulajadi, kaedah pengurusan hutan dan faktor-faktor yang memberikan kesan ke atas Sustainable Forest Management (SFM). Dalam kajian tersebut pengkaji menggunakan pendekatan kuantitatif iaitu data diperoleh melalui soal selidik yang diedarkan kepada sampel yang berstrata bagi penduduk sasaran. Daripada 160 soal selidik yang diedarkan, 115 atau 56\% telah dikembalikan. Berdasarkan analisis data mendapati bahawa terdapat beberapa persamaan serta perbezaan pandangan antara pihak berkepentingan. Majoriti responden memihak kepada peningkatan usaha pengurusan hutan sebagai salah satu cara menyelesaikan isu-isu alam sekitar yang timbul di Ulu Kinabatangan.

\section{Metodologi Kajian}

Bagi meneliti Impak penubuhan Imbak Canyon Conservation Area (ICCA) ke atas komuniti setempat di Kampung Imbak, kajian ini memberi perhatian khusus terhadap pembangunan kawasan konservasi yang berlaku di kawasan tersebut. Pendekatan utama kajian ini adalah kualitatif. Persampelan yang digunakan dalam kajian ini adalah sampel bertujuan. Manakala, kaedah kutipan data yang telah digunakan temubual mendalam. Seramai enam orang informan yang terdiri daripada ketua kampung, dua orang ahli komuniti kampung Imbak (Pengusaha Homestay dan Peniaga Kedai Runcit), dua pekerja di ICCA dan individu yang terlibat dalam pembinaan ICCA telah ditemubual. Pemerhatian juga telah dilakukan bagi mengenalpasti aktiviti harian penduduk serta mengkategorikan aktiviti penduduk kampung yang dianggap menyokong kepada usaha penubuhan kawasan konservasi ICCA.

\section{Imbak Canyon Conservation Area (ICCA)}

Imbak Canyon Conservation Area (ICCA) merupakan kawasan hutan berkeluasaan 30,000 hektar dan terletak ditengah-tengah hutan Sabah yang dikenali sebagai " The Heart of Borneo" (sabahtourism.com; diakses pada 22 Disember 2020). Selain itu, ICCA juga kaya dengan kepelbagaian biodiversiti yang menjadikan kawasan tersebut sebagai kawasan tumpuan para penyelidik. Dengan kawasan yang sangat luas dan juga tanah yang masih subur serta terjaga, ICCA merupakan satu kawasan hutan yang berusia 100 juta tahun dan mempunyai kepelbagaian yang masih banyak belum diterokai. Selain itu, ICCA ini juga terdiri dari lembah sepanjang 25-kilometer yang dikelilingi tiga sisi oleh tebing batu pasir curam setinggi 1.000 meter. Kawasan hutan belantara yang menakjubkan ini pada dasarnya membentuk ekosistem sendiri (borneoadventure.com; diakses pada 22 Disember 2020). Kerajaan Negeri Sabah mewartakan Imbak Canyon sebagai Hutan Simpan Kelas 1 (Perlindungan) pada tahun 2009. Oleh kerana lokasi dan bentuknya, ia berfungsi sebagai kawasan tadahan air yang penting untuk Sungai Kinabatangan, sungai terpanjang di Sabah. Imbak Canyon juga merupakan koridor hidupan liar yang penting yang menghubungkan dua kawasan perlindungan lain iaitu Lembah Danum dan Maliau Basin (borneoadventure.com; diakses pada 22 Disember 2020). Disamping itu, sebelum kawasan Imbak Canyon diwartakan sebagai kawasan konservasi, komuniti daripada kampung berhampiran iaitu Kampung Imbak menjadikannya tempat mencari rezeki seperti mencari kayu kayan, tempat memburu dan banyak lagi. 


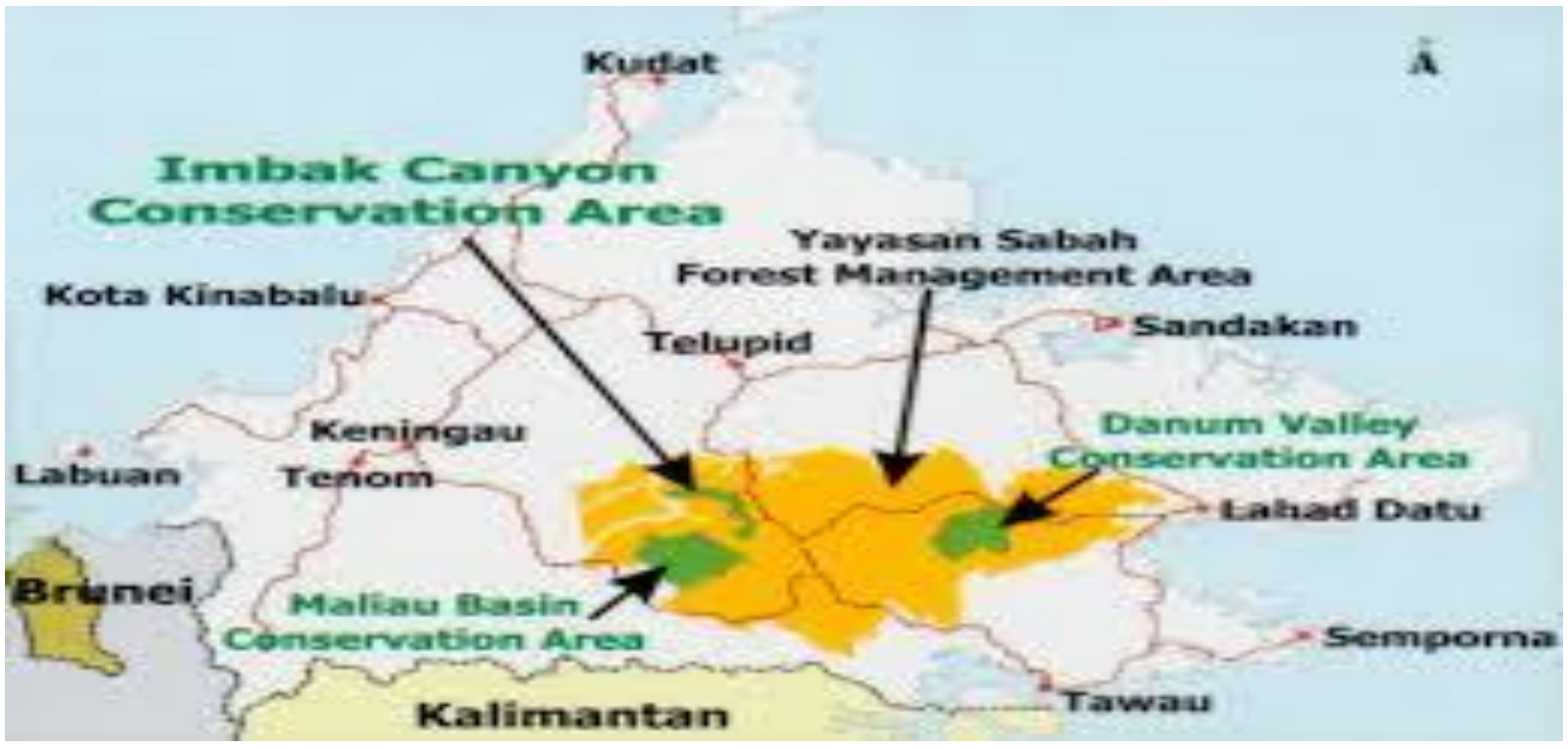

Gambar 1: Peta kedudukan Imbak Canyon Conservation Area.

Sumber: http://www.etawau.com/PlacesInterest/ImbakCanyonConservationArea.htm

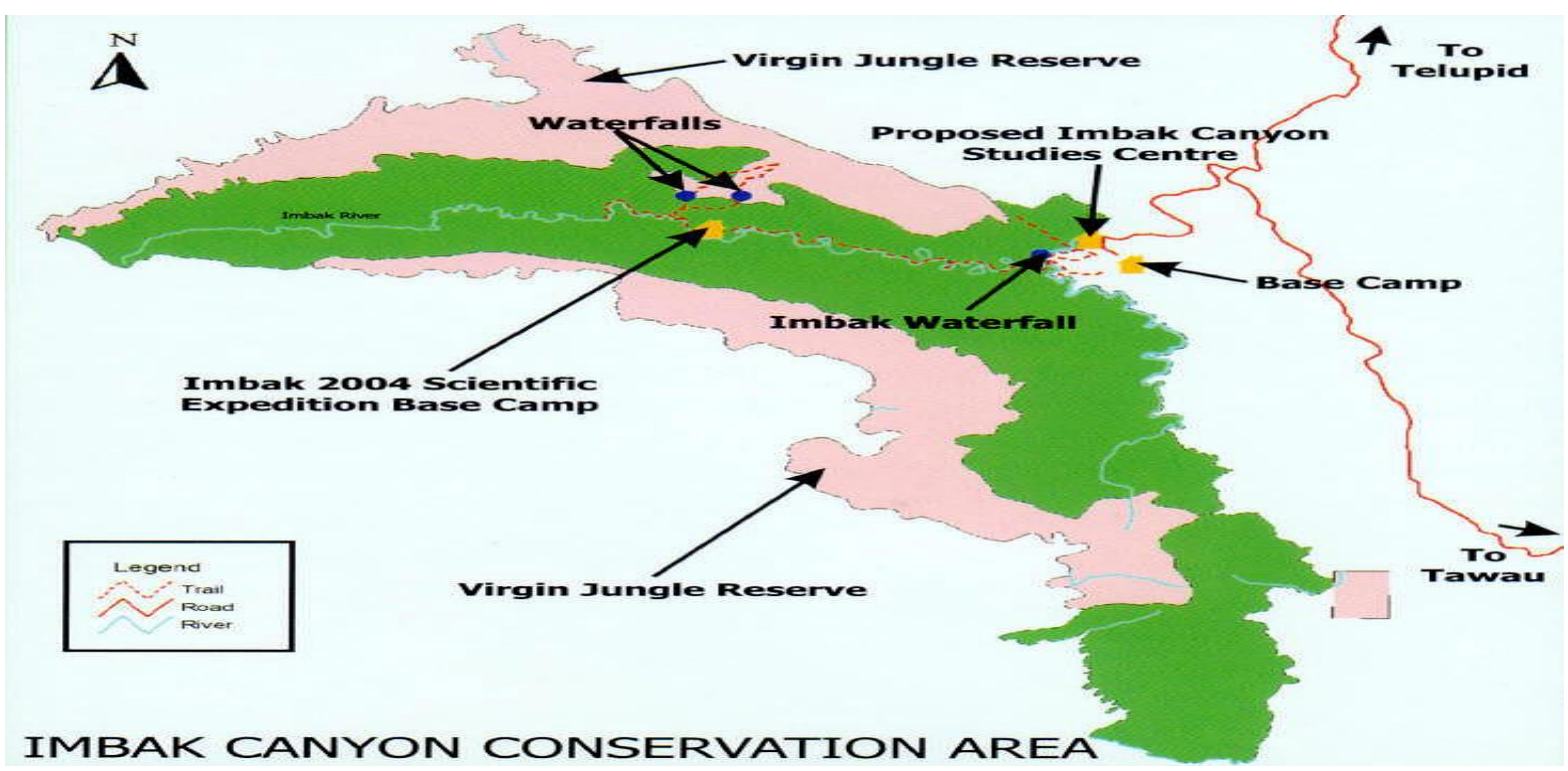

Gambar 2: Peta Imbak Canyon Conservation Area

Sumber: http://www.etawau.com/PlacesInterest/ImbakCanyonConservationArea.htm 


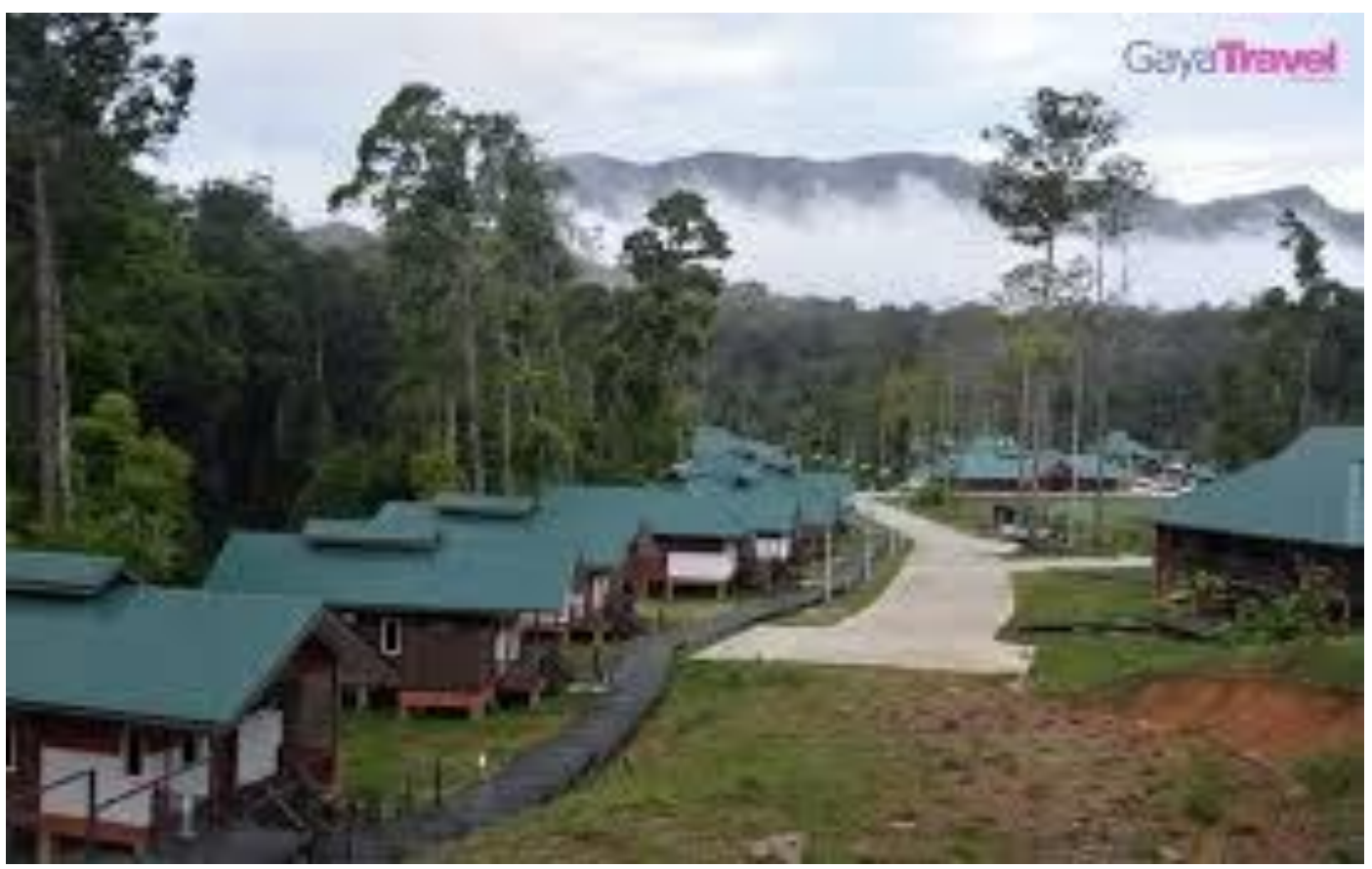

Gambar 3: Hostel/Penginapan di Imbak Canyon Conservation Area

Sumber:http://www.etawau.com/PlacesInterest/ImbakCanyonConservationArea.hm

\section{Kampung Imbak, Tongod, Sabah}

Kampung Imbak merupakan salah satu daripada 45 kampung yang terletak dalam daerah Tongod dimana majoriti penduduk kampungnya merupakan etnik asli Orang Sungai yang telah lama mendiami Ulu Kinabatangan (Rosazman, et al, 2012). Kampung Imbak masih dalam proses pembangunan dan keadaan kampung tersebut masih mundur dimana penduduk kampungnya masih mengamalkan aktiviti ekonomi sara diri. Hal ini kerana darjah ketersampaian ke kampung tersebut sangat susah kerana perlu mengunakan kenderaan pacuan empat roda untuk sampai ke kampung tersebut (Utusan Borneo, 2018). Perjalanan untuk sampai ke kampung tersebut perlu mengambil masa sekurang-kurangnya empat jam sekiranya daripada Kota Kinabalu. Selain itu, etnik Sungai yang merupakan komuniti tempatan di kampung tersebut masih hidup dalam keadaan ekonomi yang rendah kerana tidak semua penduduk kampung mempunyai tanah sendiri. Mereka juga masih bergantung dengan aktiviti ekonomi seperti pertanian sara diri, memburu, sebagai nelayan, mengumpul hasil hutan dan juga bergantung hidup sebagai pekebun kecil kelapa sawit dan getah (Samiun Bungkias, 2018).

Imbak Canyon Conservation Area (ICCA), terletak di daerah Tongod dan untuk sampai ke sana boleh menggunakan jalan darat dari Kota Kinabalu yang mengambil masa lima jam perjalanan atau daripada Sandakan yang mengambil masa empat jam perjalanan untuk sampai bergantung dengan jenis kenderaan, situasi jalan dan juga cuaca. Jaraknya kira-kira $55 \mathrm{~km}$ dari jalan utama Ranau ke Sandakan dan hanya boleh di lalui oleh kenderaan pacuan empat roda kerana jalan untuk ke ICCA masih jalan berbatu (gravel) serta perlu melalui banyak bukit tinggi. Selain itu, ICCA juga terletak berhampiran kampung Imbak yang didiami majoriti etnik Sungai. Pusat penyelidikan ICCA ditubuhkan pada 2016 tetapi kawasan pusat tersebut belum dirasmikan lagi sehingga sekarang (Waidi Sinun, 2017). 


\section{Dapatan Kajian}

\section{Penglibatan ahli komuniti sebagai ahli ekspedesi konservasi di ICCA}

Ahli komuniti yang terlibat dengan aktiviti awal penubuhan ICCA misalnya sebagai pekerja sokongan kebanyakannya merupakan komuniti setempat yang tinggal di Kampung Imbak. Ahli komuniti yang tinggal di Kampung Imbak majoritinya etnik Sungai dan mereka ialah penduduk asal dikawasan tersebut.

Sebelum Kawasan Imbak Canyon di gazet sebagai kawasan perlindungan dan pemuliharaan hutan oleh pihak kerajaan Sabah kehidupan ahli komuniti bergantung sepenuhnya dengan kegiatan ekonomi sara diri, memungut hasil hutan, sebagai nelayan sungai, sebagai pekebun kecil kelapa sawit dan juga getah. Namun dengan penubuhan kawasan konservasi Imbak kanyon sebahagian besar ahli komuniti di kampung Imbak terpaksa menyesuai dan melibatkan diri dalam aktiviti pemeliharaan dan pemuliharaan hutan tersebut. Kebanyakan ahli komuniti di kampung Imbak masih dikategorikan sebagai golongan miskin kerana pendapatan bulanan mereka masih di bawah garis kemiskinan iaitu kurang daripada RM1000 sebulan. Penubuhan kawasan perlindungan Imbak Kanyon sedikit sebanyak telah menyekat kebebasan ahli komuniti mendapatkan sumber hutan seperti sebelumnya, tetapi peluang baru kepada ahli komuniti untuk menambah pendapatan bulanan mereka adalah membantu aktiviti ekspedisi pemeliharaan hutan ini.

Pada awalnya penduduk kampung terlibat sebagai ahli ekspedisi menerokai hutan di Imbak Canyon seperti membantu mengenal pasti sumber alam semula jadi seperti lokasi air terjun dan jenis tumbuhan yang terdapat di kawasan tersebut. Selain itu, dalam ekspedisi tersebut juga ahli komuniti yang terlibat membantu mencari jalan yang sesuai untuk dibina bagi memudahkan kenderaan masuk ke kawasan Imbak Kanyon. Penglibatan ahli komuniti setempat dalam ekspedisi tersebut diperlukan oleh pihak berkuasa kerana penduduk setempat lebih mengetahui selok belok kawasan hutan tersebut berbanding orang luar. Penglibatan komuniti dalam pembangunan serta penubuhan ICCA sangat dihargai kerana ia menunjukkan bahawa komuniti setempat menyambut baik dan menyokong usaha pembangunan konservasi kawasan Imbak Kanyon (ICCA) kerana berdekatan dengan kampung mereka. Menurut Ketua Kampung Imbak En. Samiun bin Bungias penduduk kampung Imbak sudah terlibat sejak awal lagi dengan pembukaan serta penubuhan ICCA. Beliau sangat berterima kasih dengan pihak Yayasan Sabah dan Syarikat Petronas kerana mencetuskan idea untuk membuka serta menjadikan kawasan Imbak Kanyon sebagai satu kawasan konservasi dan seterusnya boleh menjadi 'destinasi' daya tarikan ekopelancongan. Dalam hal ini pndekatan yang diambil oleh pihak berkuasa Imbak Kanyon adalah selaras dengan kajian Ruiz-Mallen et al. (2015) yang mengutamakan penglibatan komuniti dan konserversi berasaskan komuniti. 


\section{Penubuhan ICCA memberi kesan postif seperti peluang pekerjaan baru kepada ahli komuniti Setempat.}

Pihak pemegang taruh Imbak Kanyon menggalakan penduduk setempat di kampung Imbak melibatkan diri dalam Program Homestay atau Inap Desa berasaskan ekopelancongan. Dengan cara ini ahli komuniti mendapat peluang untuk menjalankan aktiviti ekopelancongan melalui program inap desa tersebut. Jarak daripada Kampung Imbak ke Kawasan ICCA mengambil masa lebih kurang sejam atau pun lebih. Justeru, terdapat ahli komuniti mula berminat dan terlibat dengan Program Homestay atau inap desa. Penubuhan inap desa ini mula pada peringkat awal sekitar tahun 2010 dan seterusnya berjaya memberi penambahan pendapatan bulanan kepada para peserta. Para peserta inap desa biasanya hanya menunggu ketibaan pelancong yang dibawa oleh operator pelancongan dan menawarkan kadar sewaan rumah untuk pengunjung yang ingin melawat kawasan alam semulajadi Imbak Kanyon dalam tempoh tertentu. Para pelancong ini biasanya adalah ahli penyelidik daripada universiti tempatan dan luar negara dan ecotourists. Seperti yang dinyatakan oleh Ketua Kampung:

"Ada beberapa orang daripada penduduk kampung mula melibatkan diri sama itu homestay. Lagi pun kadang-kadang kalau pelancong mau pigi Imbak Canyon tapi sampai sini malam sudah, jadi dorang terpaksa menyewa homestay yang ada di kampung kami. Ada juga homestay yang Imbak Canyon sediakan di sini, jadi memang banyak juga lah pilihan pelancong kalau mau cari homestay." (Ketua Kampung Imbak, 2018)

Seorang pengusaha inap desa turut memberi pandangan tentang penglibatan orang kampung Imbak sebagai pengusaha homestay seperti berikut:

“...banyak juga kesan positif lepas Imbak Kanyon dibuka. Ramai orang kampung sini yang buka homestay. Saya pun salah satu pengusaha homestay disini. Yang ni memang memang rumah saya dan kami sekeluarga masih tinggal dirumah ni. Tapi kami tetap juga kasi jadi ni rumah sebagai homestay kalau ada pelancong yang mau menginap dan sewa. Buat masa ni juga rumah dan homestay saya ni belum lagi lah saya mau kasi jadi homestay sepenuhnya sebab sekarang saya ada buat satu lagi rumah dan rumah tu akan kami sekeluarga tinggal. Lepas saja rumah yang satu tu siap baru saya kasi jadi rumah lama ni sebagai homestay sepenuhnya. Saya masi juga terima pelancong yang mau tinggal di sini rumah saya tapi tidak ramai lah. Lagi pun ada juga penduduk kampung yang lain tu mengusahakan homestay jadi kami bebagi-bagi saja lah pelancong yang mau tinggal di homestay." (Pengusaha Homestay, 2018)

Selain itu, pengusaha homestay juga mendapat sumbangan atau bantuan daripada pihak berkuasa untuk penambahbaikan infrastruktur rumah atau homestay. Homestay dianggap sebagai pelaburan jangka panjang kepada penduduk kampung. Menurut penduduk kampung yang terlibat dengan program homestay ini, tahap pendapatan bulanan mereka mula berubah selepas penglibatan dalam aktiviti ekopelancongan seperti sebagai tourists guide, menyediakan penginapan pelancong dan sajian makanan kepada para pelancong. Walaupun bilangan ahli keluarga yang terlibat masih kecil namun pihak kerajaan tetap memberikan tumpuan kepada mereka dengan memberikan bantuan serta sumbangan dalam bentuk peralatan dan khidmat nasihat kepada pengusaha homestay. Bantuan peralatan yang mereka perolehi adalah peralatan 
penambahbaikkan infrastruktur homestay seperti simen, bata, kayu, papan dan alat-alat lain. Seperti yang dinyatakan oleh Ketua kampung Imbak:

"Pengusaha homestay di kampung ini mendapat bantuan daripada kementerian Pelancongan selepas saya dan JKKK kampung Imbak iaitu Cik Linda membantu serta menghantar surat permohonan bantuan kepada pihak atasan. Sekarang ni bantuan yang sudah diluluskan ada di Pusat Maklumat dan belum diagihkan. Bantuan yang mereka dapat lebih kepada peralatan penambahbaikkan homestay macam simen, bata sama alat-alat lain." (Ketua Kampung Imbak, 2018).

Antara faedah atau kebaikan penubuhan ICCA juga ialah ahli komuniti dapat memulakan perniagaan secara kecil-kecilan seperti pembukaan kedai runcit. Penubuhan ICCA sebagai satu kawasan pemuliharaan, penyelidikan dan juga satu kawasan pelancongan telah mendorong penduduk kampung mengusahakan kedai runcit. Beberapa orang penduduk kampung telah melibatkan diri dalam pembukaan kedai runcit di tepi jalan raya yang menjadi laluan kepada kenderaan yang menuju ke ICCA dan juga kenderaaan berat seperti lori yang mengangkat kayu balak. Pada awalnya, mereka buka kedai runcit hanya untuk menampung serta menambah pendapatan isi rumah mereka sahaja. Namun, tanpa dijangka kedai mereka menjadi tempat persinggahan pelancong yang menuju ke ICCA. Seperti yang dijelaskan oleh ketua kampung Imbak:

"Lepas tu ada juga yang membuka kedai runcit selepas dorang nampak kampung ni jadi tempat singgah pelancong yang mau pigi Imbak Kanyon. Kalau kedai runcit, ada tu situ siring jalan, beberapa buah kedai runcit diusahakan oleh orang kampung sini. Satu sebab dorang buka kedai runcit sebab kalau orang kampung mau beli barang - barang nda perlu keluar pigi luar. Lagi pun susah mau keluar pigi pekan kalau tiada kenderaan sendiri. Jadi senang sikit lah kami mau beli barang lepas penduduk kampung sendiri buka kedai macam sekarang ni. Lepas tu, kalau ada pelancong yang datang sini sama yang mau pigi Imbak Canyon, dorang singgah juga tu di kedai-kedai runcit untuk beli barang kelengkapan dorang. Apa yang saya nampak lah, lepas ja satu persatu pembangunan yang kerajaan buat sini macam pembukaan tu imbak Canyon, banyak sudah perubahan dalam ekonomi penduduk sini." (Ketua Kampung Imbak, 2018).

Seorang peniaga kedai runcit memberi pandangan beliau tentang faedah penubuhan ICCA terhadap peluang pekerjaan yang wujud di kampung Imbak:

"Satu lagi yang saya nampak, perusahan kedai runcit saya sama orang kampung yang lain bertambah maju. Dulu masa saya mau buka kedai runcit sebenarnya hanya untuk memudahkan penduduk kampung mendapatkan keperluan asas yang dorang perlukan. Sebab jauh mau keluar pergi pekan Telupid atau pekan Tongod kalau mau membeli. Pada awalawal ICCA dibuka belum lagi ramai pelancong masuk sini sebab dorang belum tau lagi kan, tapi lepas satu tahun atau atau tahun lalu kah tu mula sudah ada pelancong masuk, lepas tu ada yang singgah membeli di kedaikedai runcit sini. Apa yang saya perasaan pelancong asing ni suka singgah di tempat-tempat begini kira macam kawasan kampung lah. Dorang pun membeli barang juga dari kedai runcit saya dan ada barang yang dorang perlukan tu tiada saya jual. Jadi dari situ saya fikir untuk kasi besar ni kedai supaya boleh saya kasi tambah lagi barang - barang jualan saya. Selain 
pelancong asing, ada juga pelancong tempatan dari tempat lain yang datang, dorang pun ada singgah sini juga membeli." (Peniaga kedai Runcit, 2018).

Justeru, hasil dapatan kajian ini menepati tipologi tahap penglibatan ahli komuniti dalam pembangunan oleh Pretty (1995). Tahap penglibatan ahli komuniti di kampung Imbak dengan penubuhan ICCA telah bergerak daripada tahap pasif (penduduk yang terlibat biasanya di jemput oleh pihak berkuasa untuk menjayakan sesuatu projek pembangunan) kepada tahap insentif (ahli komuniti terlibat dalam menyumbangkan tenaga kerja untuk mendapatkan faedah dalam bentuk nilai mata wang atau material lain). Jika kesan positif ini kekal bertahan adalah tidak mustahil tahap penglibatan ahli komuniti di kampung Imbak boleh mencapai tahap penglibatan interaktif iaitu ahli komuniti terlibat melalui proses pendidikan, mengukuhkan institusi tempatan dan dapat mengawal sumber serta mencapai matlamat projek seperti yang telah di rancang dan ditetapkan tersebut. Maka objektif untuk mencapai konsep 'konserversi berasaskan komuniti' di Kawasan ICCA akan menjadi realiti akhirnya.

\section{Cabaran dan Limitasi Yang Dihadapi Oleh ahli Komuniti Setempat di Kampung Imbak bagi mencapai pendekatan konservasi berasaskan komuniti yang mampan.}

\section{Peluang pekerjaan yang ditawarkan di ICCA masih terhad.}

Terdapat banyak cabaran dan juga limitasi yang masih dihadapi oleh ahli komuniti setempat di Kampung Imbak bagi mencapai pendekatan konservasi berasaskan komuniti yang mampan. Antaranya ialah peluang pekerjaan yang masih terhad merupakan salah satu cabaran yang masih dihadapi oleh sebahagian besar penduduk kampung. Walaupun penubuhan ICCA memberi peluang pekerjaan kepada sebilangan kecil ahli komuniti namun ianya belum cukup untuk menampung permintaan pekerjaan kepada sebahagian besar ahli komuniti di kampung Imbak. Pihak pengurusan ICCA hanya mengambil pekerja daripada kampung Imbak seramai 5 ke 10 orang pekerja sahaja. Masih ramai penduduk kampung yang tidak diambil berkerja dan mereka masih mencari-cari peluang pekerjaan yang ada. Kebanyakan penduduk kampung Imbak sudah tidak mampu untuk bergantung sepenuhnya dengan pekerjaan sebagai nelayan dan juga buruh. Hal ini kerana sumber ikan yang semakin berkurangan dan pendapatan yang yang diterima tidak menentu untuk memenuhi pembelian keperluan asas yang diperlukan untuk kehidupan seharian. Keadaan ini di nyatakan oleh seorang pengusaha homestay:

"Banyak masalah yang ada di kampung ni sebab Kampung Imbak sangat bergantung sama itu Imbak Canyon sebab sana tawarkan pekerjaan. Tapi masalahnya dia tidak dapat menampung jumlah penduduk kampung sini yang masih mencari peluang pekerjaan yang tetap." (Pengusaha Homestay, 2018) 


\section{Kekurangan kemudahan infrastruktur di Kampug Imbak}

Selain itu, kampung Imbak masih menghadapi isu kekurangan kemudahan infratruktur asas seperti jalanraya bertar, bekalan air paip dan bekalan elektrik 24 jam. Masalah jalan raya yang masih tidak berturap menuju ke pusat ICCA merupakan masalah yang sudah lama dihadapi oleh penduduk kampung Imbak. Keadaan ini memberikan banyak kesukaran kepada penduduk serta pelancong yang ingin datang ke homestay kampung Imbak kerana kualiti jalan raya yang yang rendah. Pada masa kini jalan raya daripada pekan Telupid menuju ke pekan Tongod sudah ditahap yang baik kerana sudah diturap. Tetapi jalan masuk ke kampung-kampung dalam daerah Tongod dan ke kawasan ICCA masih gravel dimana ianya hanya boleh dilalui dengan menggunakan kereta pacuan empat roda. Jalan untuk menuju ke kampung Imbak serta ICCA berada dalam kondisi yang kurang baik kerana banyak lubang besar yang boleh membuatkan kereta kecil terkandas serta tidak boleh melaluinya. Jalan kampung dan sekitarnya merupakan jalan yang berbatu dan juga tanah merah. Apabila hujan lebat ia akan menyukarkan kenderaan kecil atau besar untuk melalui jalan tersebut kerana permukaan jalan yang licin. Seperti yang dinyatakan oleh Ketua Kampung Imbak:

"Masalah utama kami disini masalah habuk. Dari dulu masalah kami ni tiada jalan penyelesaian. Susah juga mau kawal sebab laluan kampung kami ni menjadi laluan pigi Imbak Canyon sama laluan lori kayu balak dari Kampung Inarad. Jalan raya di kampung kami sampailah di Imbak canyon memang masih batu sama tanah. Kalau hujan lagi teruk sebab susah mau keluar. Banyak jalan tida boleh kena limpas sebab belumpur. Kami ingat kalau kena buka suda itu Imbak canyon, kami punya jalan raya pun kena kasi aspal(turap) juga supaya senang kalau mau pergi sana tapi rupanya tiada juga kena kasi bagus" (Ketua Kampung Imbak, 2018).

\section{Kemudahan jaringan komunikasi internet yang terhad.}

Seterusnya, dapatan kajian ini juga menunjukkan kemudahan jaringan komunikasi di kampung Imbak adalah terhad. Kualiti kemudahan capaian jaringan komunikasi yang rendah juga merupakan salah satu masalah yang telah lama dihadapi oleh penduduk kampung Imbak. Jaringan komunikasi internet merupakan satu keperluan yang sangat penting kepada penduduk tempatan dan juga pelancong yang berada di kawasan tersebut untuk berhubung dengan ahli keluarga dan pihak lain yang berada di luar kampung Imbak. Namun begitu, jaringan komunikasi seperti rangkaian telefon dan juga internet di kampung Imbak sangat rendah tahap kualitinya. Penduduk kampung Imbak dan pelancong tidak dapat membuat panggilan telefon bimbit. Walaupun dalam keadaan tertentu signal rangkaian telefon kuat, para pengguna di kampung Imbak hanya boleh menghantar pesanan ringkas atau mesej sahaja. Situasi ini sangat mengecewakan penduduk kampung kerana di kawasan kampung lain dalam daerah Tongod sudah mempunyai sistem rangkaian komunikasi yang lebih baik seperti di kawasan bandar Tongod. Situasi ini diperjelaskan oleh ketua kampung Imbak seperti berikut: 
"Sejak kampung ni ditubuhkan langsung tiada kemudahan line telefon, jadi kalau mau bertelefon perlu keluar sana Telupid. Itu pun mengambil masa yang lama sebab jalan masih belum ada aspal. Sekarang ni pula ada suda line telefon tapi mau telefon orang pun nda dapat sedangkan full juga line telefon. Mesej saja dapat, apa lagi kalau musim hujan, hilang terus tu line telefon di kampung ni." (Ketua Kampung Imbak, 2018).

Isu kemudahan internet yang terhad ini turut diperkatakan oleh seorang peniaga kedai runcit di kampung Imbak seperti berikut:

"Susah sekarang ni di kampung kami, ada juga rangkaian telefon tapi tidak kuat. Mau bertelefon pun tidak dapat, mesej saja dapat buat masa sekarang. Lepas tu line yang kuat pun line celcom saja. Kalau yang macam maxis sama digi tida dapat langsung tu, ada masa-masanya baru dapat. Kalau mau bertelefon pun kadang-kadang perlu cari tempat-tempat tertentu ja yang boleh bertelefon." (Peniaga Kedai Runcit, 2018)

Menurut ketua kampung dan beberapa ahli komuniti yang ditemui mengatakan bahawa masalah rangkaian telekomunikasi telefon di kampung mereka yang terhad menyukarkan mereka berhubung dengan pembekal-pembekal barang kedai runcit. Selain itu, sekiranya berlaku hal-hal kecemasan yang memerlukan bantuan perubatan ataupun perkhidmatan pihak berkuasa seperti polis, bomba dan ambulan, sukar untuk mereka membuat panggilan kecemasan yang sewajarnya.

\section{Penguatkuasaan Undang-Undang di Kawasan Perlidungan Hutan ICCA}

Setelah ICCA digazetkan ahli komuniti setempat mula dihalang oleh pihak berkuasa rangers menggunakan sumber hutan dalam kawasan ICCA. Oleh kerana kawasan Imbak Kanyon telah diwartakan menjadi kawasan konservasi ahli komuniti tidak lagi dapat masuk ke hutan dengan bebas seperti sebelumnya untuk mendapatkan sumber seperti kayu kayan, memburu binatang, mencari herba hutan dan sebagainya. Aspek ini telah menjadi isu dan konflik kepentingan antara penduduk kampung dan pihak berkuasa yang melindungi kawasan ICCA. Menurut Ketua Kampung Imbak ahli komuniti di kampung tersebut mula meluah kepadanya berkaitan larangan menggunakan sumber hutan tersebut. Namun, kebanyakan mereka mengakui bahawa mereka tidak dapat berbuat apa-apa sebab kerajaan negeri Sabah sudah pun mewartakan serta menjadikan hutan di ICCA asset alam semulajadi yang dilindungi, walau pun pada suatu masa dulu hutan di Imbak Canyon adalah tempat mereka mencari rezeki dalam kehidupan harian. Ketua kampung Imbak mengatakan:

"Ada juga luahan penduduk disini yang cakap tidak sudah dapat masuk sana (ICCA) kalau mau cari kayu sama memburu. Kena jaga sudah hutan sana supaya tiada orang ceroboh masuk "(Ketua Kampung Imbak, 2018). 


\section{Bilangan kehadiran pelancong ke homestay Kampung Imbak masih kecil bilangannya}

Secara relatifnya kehadiran pelancong menginap di homestay kampung Imbak masih kurang. Ini disebabkan kawasan alam semualajadi Imbak Kanyon masih baru ditubuhkan. Masih ramai orang luar yang kurang mengetahui mengenai homestay kampung Imbak kerana kurang promosi. Hal ini menyebabkan pengusaha homestay tidak menerima kehadiran pelancong yang ramai. Selain itu, ia turut menjejaskan pendapatan pengusaha homestay sebagai pendapatan utama mereka. Pada masa sama masalah infrastruktur seperti jalanraya dan tiadanya bekalan air paip juga adalah faktor yang menyebabkan homestay di kampung Imbak tidak mendapat sambutan daripada pelancong. Menurut pengusaha homestay di kampung Imbak, pelancong yang menginap di homestay mereka sangat kurang kerana kebanyakkan pelancong yang datang terus ke hostel pusat penyelidikan ICCA dan menginap di situ.

"Ada juga pelancong yang datang tapi kadang saja mereka menginap di sini. Kebanyakkannya terus pigi Imbak Canyon biarpun malam sudah mereka sampai”. (Pengusaha Homestay, 2018).

Manakala persaingan dengan operator pelancongan swasta dari luar juga adalah salah satu cabaran kepada para pengusaha homestay di kampung Imbak untuk mendapatkan pelancong menginap di homestay mereka. Biasanya operator pelancong swasta membuat iklaniklan yang menarik sehinggakan para pelancong tertarik untuk mendapatkan khidmat tour guides daripada syarikat mereka. Ahli komuniti yang baru sahaja melibatkan diri dalam perogram homestay ini tidak mampu bersaing dengan operator pelancong swasta yang lebih berpengetahuan dan mahir dalam aktiviti ekopelancongan. Hal ini dapat dilihat daripada pakejpakej yang ditawarkan oleh operator pelancongan swasta di lawan web mereka.

Kombinasi antara pemandangan hutan hujan yang menakjubkan, peluang untuk melihat hiduapan liar dan kemudahan fasiliti penginapan yang baik menjadikan imbak Canyon destinasi yang hebat untuk pengembara yang adventurous. Aktiviti lain termasuklah jungle trekking, memerhati burung dan hidupan liar, photography dan night walks, memandu 4WD diwaktu malam, berkhemah di hutan hujan di Pusat Penyelidikan Kuli. Anda juga boleh menikmati keindahan air terjun terutamanya air terjun Imbak Canyon yang luasnya 39 meter (borneoadventure.com).

Syarikat borneoadventure.com ini meneruskan lagi promosi mereka:

Borneo Adventure pada masa kini beroperasi dan menawarkan 4-hari, 3 malam pakej pelancongan ke Imbak Canyon. Dalam kumpulan kecil pelancong (max 6 orang) kita akan berlepas setiap hari Isnin. Jika anda berminat tidak perlu menunggu lagi, tempah perjalanan anda dan email kami segera (borneoadventure.com). 


\section{Kesimpulan}

Hasil kajian ini jelas menunjukkan bahawa penubuhan ICCA telah mengakibatkan kesan positif dan negatif ke atas ahli komuniti setempat di kampung Imbak Canyon. Dalam satu aspek kajian ini jelas menunjukkan bahawa terdapat ahli komuniti setempat di kampung Imbak yang tinggal berhampiran kawasan ICCA terlibat dengan proses dan aktiviti konservasi. Ini berlaku apabila pihak kerajaan negeri Sabah mewartakan Imbak Canyon Conservation Area (ICCA) sebagai kawasan pemuliharaan dan perlindungan alam semulajdi dan juga sebagai destinasi ekopelancongan. Selain itu, penubuhan ICCA memberikan impak yang positif terhadap perubahan tahap sosio-ekonomi penduduk setempat. Penubuhan ICCA membolehkan penduduk setempat melibatkan diri dalam proses pemeliharaan alam semula dengan wujudnya peluang pekerjaan baru yang ditawarkan kepada sebilangan penduduk tempatan di kampung Imbak. Namun, usaha positif ini harus dilaksanakan secara berterusan oleh pihak berkuasa agar ahli komuniti setempat dan juga kawasan konservasi ICCA tersebut mendapat faedah bersama dalam jangka masa yang panjang melalui konsep 'konservasi berasaskan komuniti'.

Disamping itu, dalam satu aspek lain, hasil kajian ini menunjukkan bahawa penglibatan ahli komuniti masih berada di tahap pasif mengikut tipologi penglibatan komuniti oleh Pretty (1995). Hal ini kerana kebanyakan ahli komuniti hanya terlibat pada peringkat awal sahaja seperti sebagai ahli ekspedesi penerokaan hutan dan pekerja manual. Mereka tidak terlibat dalam membuat keputusan kerana aspek ini dilakukan oleh pihak pemaju dengan agensi yang lain. Hasil kajian ini juga menunjukkan bahawa ahli komuniti tidak terlibat secara langsung dengan usaha konservasi pada setiap masa tetapi mereka hanya menyokong usaha tersebut secara tidak langsung dengan melibatkan diri dalam aktiviti homestay berasaskan ekopelancongan. Hasil kajian ini jelas menunjukkan bahawa penglibatan ahli komuniti di kampung Imbak melalui 'Pendekatan Konservasi Berasaskan Komuniti' (CBCA) masih belum dicapai sepenuhya. Ini kerana dalam pelaksanaan konservasi di ICCA pihak berkuasa masih cenderung melaksanakan konsep 'konserversi kubu' di mana komuniti yang tinggal di kawasan berhampiran ICCA dihalang untuk masuk dan menggunakan sumber hutan sebagaimana amalan dan kelangsungan hidup mereka yang bergantung dengan sumber hutan sejak turun temurun sebelum ini. Demi mengurangkan tension dan konflik kepentingan antara ahli komuniti setempat dan pihak berkuasa, pelaksanaan 'konservarsi berasaskan komuniti' perlu dipertimbangkan dengan sewajarnya dalam masa yang terdekat ini oleh pihak berkuasa di ICCA.

\section{Rujukan}

\section{Jurnal dan Buku}

Agyeman, Y. B., Yeboah, A. O., \& Ashie, E. (2019). Protected areas and poverty reduction: The role of ecotourism livelihood in local communities in Ghana. Community Development, 50(1), 73-91

Anthony, B. 2007. The dual nature of parks: attitudes of neighbouring communities towards Kruger National Park, South Africa. Environmental Conservation 34:236-245.

Armitage, D.R., Plummer, R. Berker, F., Arthur, R. I, Charles, A.T., Johmsom, Arthur Hoole. 2008. Community-Based Conservation and Protected Areas in Namibia: Social-Ecological Linkages for Biodiversity. Natural Resources Institute University of Manitoba Winnipeg, Manitoba. 
Armitage, D. R., Plummer, R., Berkes, F., Arthur, R. I., Charles, A. T., Davidson-Hunt, I. J., \& McConney, P. 2009. Adaptive co-management for social-ecological complexity. Frontiers in Ecology and the Environment, 7(2), 95-102.

Aswani, S., and P. Weiant. 2004. Scientific evaluation in women's participatory management: monitoring marine invertebrate refugia in the Solomon Islands. Human Organization 63(3):301-319.

Brian Rotich. 2019. Forest Conservation and Utilization in Embobut, Cherangani Hills, Kenya. Department of Environment and Resources Development, Chuka University, Chuka, Kenya. International Journal of Natural Resource Ecology and Management 2019; 4(1):713.

Berkes, F. 2004. Rethinking community-based conservation. Conservation Biology, 18(3):621630.

Berkes, F. 2009. Community conserved areas: policy issues in historic and contemporary context. Conservation Letters, 2(1), 20-25.

Brown, K. 2003. Integrating conservation and development: a case of institutional misfit. Frontiers in Ecology and the Environment 1(9):749-487.

Ceballos-Lascurain H. (1996). Tourism, ecotourism and protected areas. Gland, IUCN, Switzerland.

Chape, S., Spalding, M., Taylor, M., Putney, A., Ishwaran, N., Thorsell, J., Blasco, D., Robertson, J., Bridgewater, P., Harrison, J. \& McManus. E. 2008. History, definitions, value and global perspective. Pages 1-35 in S. Chape, M. Spalding, and M. Jenkins, editors. The world's protected areas-status, values and prospect in the 21 st century. University of California Press, Los Angeles, California, USA.

Eshun, G., \& Tichaawa, T. M. (2020). Towards sustainable ecotourism development in Ghana: Contributions of the local communities. Tourism: An International Interdisciplinary Journal, 68(3), 261-277.

Fennel, D. 1999. A. 1999: Ecotourism: An introduction. Routledge, London.

Ghimire, K. B., and M. P. Pimbert, editors. 1997. Social change and conservation. Earth Scan, London.

Goodwin, H. 1996. In pursuit of ecotourism. Biodiversity \& Conservation, 5(3), 277-291.

Grainger, J. 2003. People are living in the park. Linking biodiversity consereavtion to community development in the Middle East region: a case study from the Saint Katherine Protectorate, Sourthern Sinai. Journal of Arid Environment 54:29-38.

Hayes T. M. 2006. Parks, people, and forest protection: an institutional assessment of the effectiveness of protected areas. World Development 34(12):2026-2075.

Hussin, R. 2008. Ecotourism and community participation in the homestay programme of Sukau village: long-term or limited benefits? SARJANA, [S.1.], v. 23, n. 1, p. 72-86,

Keogh, B. 1990. Public participation in community tourism planning. Annals of Tourism Research, 17, 449-465.

Lane, M. B. 2001. Affirming new directions in planning theory: Co-management of protected areas. Society and Natural Resources 14:657-671.

Leader-Williams, N., Adams, W.M. \& Smith, R.J. (eds). 2011. Trade-offs in Conservation: Deciding What to Save. John Wiley \& Sons, Chichester, UK.

Mascia, M. B. 2003. The human dimension of coral reef marine protected areas: recent social science research and its policy implication. Conservation Biology 17(2): 630-632.

Mason, M. (2003). Tourism Impacts, Planning and Management, Oxford: Elsevier. 
MIPL. 2010. Konservasi. Purwokerto: STMIK AMIKOM

Murphree, M. W. 2002. Protected areas and the commons. Common Property Resource Digest 60:1-3.

Pretty, J., and D. Smith. 2004. Social capital in biodiversity conservation and management. Conservation Biology 18(3):631-638.

Reed, M. S. 2008. Stakeholder participation for environmental management: a literature review. Biological Conservation 141:2417-2431.

Rosazman, H., Jalihah, M.S., Dayu, S. 2012. Siri Etnik Sabah ITBM-UMS; Orang Sungai. Institut Terjemahan \& Buku Malaysia dan Univeersiti Malaysia Sabah; Kuala Lumpur.

Ross, S dan Wall, G. 1999. Evaluation Ecotourism: The case of North Sulawesi. Tourism Management in press, Indonesia.

Ruiz-Mallén, I., Schunko, C., Corbera, E., Rös, M., \& Reyes-García, V. 2015. Meanings, drivers, and motivations for community-based conservation in Latin America. Ecology and Society, 20(3).

Scheyvenes, R. 1999. Case Study: Ecotourism and the empowerment of local communities. Tourism Management, 245-249.

Wilshusen, P. R., S. R. Brechin, C. L. Fortwangler, and P. C. West. 2002. Reinventing a square wheel: critique of a resurgent "protection paradigm" in international biodiversity conservation. Society and Natural Resources 15:17-40.

Western, D. \& R.M. Wright. 1994. The background to community-based conservation. In: Western, D., R.M. Wright \& S.C. Strum (Eds.). Natural Connections: Perspectives in Community-Based Conservation. Pp.1-12. Island Press. Washington.

World Resources Institute, World Conservation Union, United Nations Environmental Programme (WRI, IUCN, UNEP). 1992. Global biodiversity strategy. Washington, D.C.

\section{Temu Bual}

Samiun Bungkias, 62 tahun, Ketua Kampung Imbak. Kampung Imbak, Tongod Sabah. 15 April 2018 .

Pengusaha Homestay, 45 tahun, Penduduk kampung Imbak dan Pengusaha Homestay. Kampung Imbak, Tongod, Sabah. 15 April 2018.

\section{Laman Web}

https://www.sabahtourism.com/destination/imbak-canyon-conservation-area/ Diakses Pada 22 Disember 2020.

http://www.etawau.com/PlacesInterest/ImbakCanyonConservationArea.htm Diakses Pada 22 Disember 2020

https://borneoadventure.com/destinations/imbak-canyon/ Diakses Pada 22 Disember 2020

https://www.borneoecotours.com/tours/family.php Diakses Pada 22 Disember 2020 